\title{
A NEW SPECIES OF CLADAITINA MAHESHWARI \& MEYEN, 1975 (CORDAITALEAN POLLEN) FROM UPPERMOST PERMIAN DEPOSITS OF THE FAMATINA RANGE, CENTRAL WESTERN ARGENTINA
}

\author{
ANA MARÍA ZAVATTIERI \\ IANIGLA, CCT-CONICET, Mendoza, Argentina.amz@mendoza-conicet.gov.ar \\ PEDRO RAÚL GUTIÉRREZ \\ Sección Paleopalinología, Museo Argentino de Ciencias Naturales "Bernardino Rivadavia", \\ Buenos Aires, Argentina. pedroraulgutierrez@gmail.com
}

\begin{abstract}
A new cordaitalean pollen species of Cladaitina Maheshwari \& Meyen, namely Cladaitina veteadensis is described from the Upper Permian strata of Argentina. The morphology of these dispersed pollen grains were studied using light and scanning electron microscopy. Detailed comparisons are made with similar commonly recorded sporae dispersae incertae sedis forms mainly recorded from other Late Permian palynofloras elsewhere. Cladaitina veteadensis sp. nov. constitutes a characteristic and common component of a rich palynological assemblage found in the upper part of the La Veteada Formation, Famatina Range, La Rioja province, central-western Argentina. More than 40 genera of pollen grains, spores, algae and fungi were recognized in this assemblage that they collectively suggest a latest Permian age. The presence of the genus Cladaitina in Argentina can be considered as a first evidence of the occurrence of Rufloriaceae in Gondwana.
\end{abstract}

Key words: Palynology, cordaitalean pollen, Cladaitina, Upper Permian, La Veteada Formation, La Rioja.

RESUMO - É descrita uma nova espécie do pólen de Cordaitales do gênero Cladaitina Maheshwari \& Meyen, denominada Cladaitina veteadensis sp. nov., para o Permiano Superior da Argentina. A morfologia, desses grãos de pólen dispersos, foi estudada em microscopia de luz transmitida e eletrônica de varredura e, comparada em detalhe, com a de palinomorfos semelhantes, na maioria, registrados como sporae dispersae incertae sedis, em microfloras do Permiano Superior em outras localidades. Cladaitina veteadensis sp. nov. é comum na associação palinológica encontrada no topo da Formación La Veteada, Sistema Famatina, La Rioja, no centro-oeste da Argentina. Mais de 40 tipos de pólen, esporos, algas e fungos foram reconhecidos nesta associação que sugere idade Permiano Superior. A presença de Cladaitina na Argentina pode ser considerada a primeira evidência da presença de Rufloriaceae no Gondwana.

Palavras-chave: Palinologia, pólen de Cordaitales, Cladaitina, Formação La Veteada, Permiano Superior, La Rioja.

\section{INTRODUCTION}

A palynological assemblage containing palynomorphs in moderate to excellent states of preservation came from the type locality of the La Veteada Formation (Dávila et al., 2005), north of the La Rioja Province, central western Argentina (Figure 1A). This area is located on the eastern edge of the central Famatina Range, west of the Los Ángulos town. In this region, Dávila et al. (2005) described a sedimentary section of $\sim 180 \mathrm{~m}$ thick of lenticular bands of evaporites and laminated dolomites interlayered by mudstones (limestones and claystones) and sandstones sheets. They named this succession as La Veteada Formation whose type section was defined on the eastern limb of the Los Colorados anticline, close to its northern plunging zone (Figure 1A). The thick evaporitic layers, which locally reach to $\sim 23 \mathrm{~m}$ thick were interpreted by those authors as recurrence of tectonical forces.
Dávila et al. (2005, fig. 1) show the stratigraphic summary of the regional outcrops. In the Famatina System, the Paganzo Group encompasses the following time intervals and units, from base to top: Upper Carboniferous, Agua Colorada Formation (Turner, 1964); Permian, De la Cuesta Formation (Turner, 1964) and La Veteada Formation (Dávila et al., 2005). An age range of Middle Permian to Late Permian is suggested for the La Veteada Formation (Gutiérrez et al., 2011) that crops out regionally, by comparing the preliminary palynological results with previously published Permian palynological studies on South American strata (Césari \& Gutiérrez, 2001).

In the type section (La Yesera, $28^{\circ} 38^{\prime} \mathrm{S} / 67^{\circ} 46^{\prime} \mathrm{W}$; see Figure 1A), the upper part of the La Veteada Formation overlies para-conformably by fluvio-eolian Permian deposits of De la Cuesta Formation and unconformably underlies Lower Miocene sequence of the Del Crestón Formation (Turner, 1964) (see Figure 1B). 
According to Dávila et al. (2005), the whole type succession of the La Veteada Formation is developed from basal grey silcrete, which can be recognized in the studied area. Above this chert-level, the facies of the unit consists mainly of medium to coarse tabular sandstones and fine-grained conglomerates lenses hardly silicified with subrounded clasts. Upwards it is formed by rhythmic interbedding fine sandstones and fine to very fine dark grey laminated siltstones and claystones, locally interbedded with gypsum levels. The nodular to prismatic gypsum bands are distributed irregularly forming locally thick lenticular strata of rhythmic evaporites and stromatolitic laminated limestones (Figure 1B).

The development of nodular and prismatic gypsum at the base of the succession suggests precipitation of evaporites in floodplains under high evaporation conditions in which the fluctuation of the phreatic water table has been periodical either nearby lacustrine hipersaline bodies and/or in saline sheedloads (Ezpeleta, 2009). In summary, the sedimentary environment was interpreted by Dávila et al. (2005) as extent hypersaline systems, which supported low-relief settings.

From the outcropping section of the La Veteada Formation at the La Yesera locality, a rich and diverse palynological assemblage was recorded (Figure 1B), in which one of the common component is herein described.

In the present paper a new species of the genus Cladaitina is fully described and illustrated. The new species constitutes between 5 and 32 percent of the total spore-pollen assemblage, which is generally well preserved. Accordingly, a comprehensive review of this dispersed pollen of Cordaitalean affinity has been undertaken.

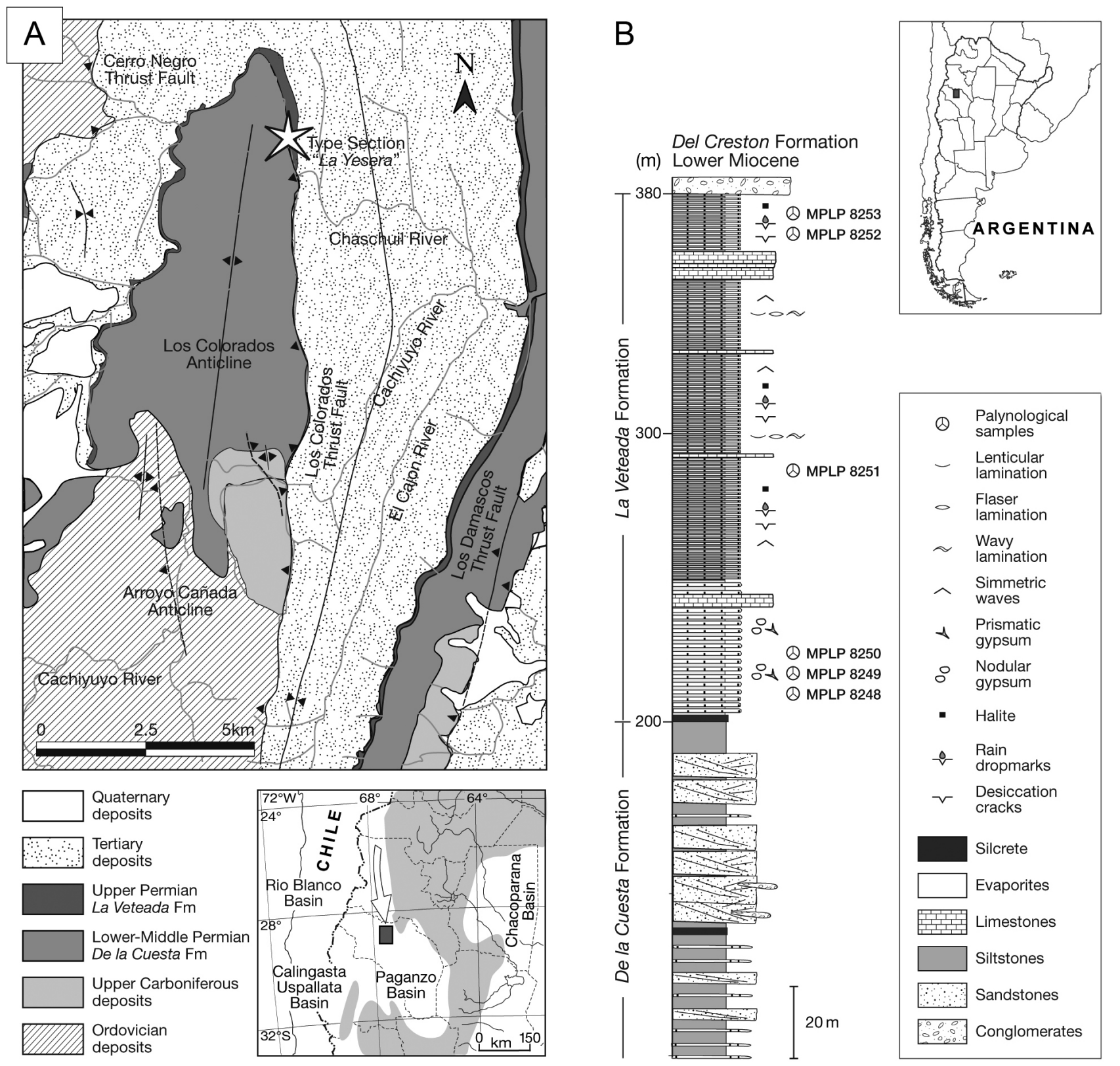

Figure 1. A, geological map of the study area, central Famatina Range, La Rioja Province, showing the location of the fossiliferous type section of the La Veteada Formation; B, section summarizing part of the Permian deposits cropping out at Los Colorados Anticline, type section of the La Veteada Formation and location of the studied palynological samples (modified from Dávila et al., 2005). 


\section{MATERIAL AND METHODS}

Six outcrop samples of pelitic levels were available for palynological study yielding abundant and diverse spore-pollen and freshwater algae assemblages from the type section of the La Veteada Formation (Figure 1B). The samples were processed using standard palynological $\mathrm{HCl}-\mathrm{HF}$ acid maceration techniques, and were sieved using a $10 \mu \mathrm{m}$ mesh and finally mounted in glicerine jelly. Some organic residues were slightly oxidized as required. The slides were examined using a light microscope Olympus BX 50 and the photomicrographs were taken with an Olympus digital camera of the Paleopalynology Unit, of the Argentinian Institute of Nivology, Glaciology and Environmental Sciences (IANIGLA), CCT-CONICET, Mendoza, and with an optical light microscopy Nikon H550S and adapted Nikon digital camera DS-Fil from the Paleopalynologic Laboratory, Museo Argentino de Ciencias Naturales "Bernardino Rivadavia" (MACN), Buenos Aires, Argentina. The palynological slides are housed in the Paleopalynological Collection of the former Institution. The slides are identified by the catalogue numbers 8248-8253 followed by the abbreviation MPLP (MendozaPaleopalinoteca-Laboratorio de Paleopalinología). Specimen locations are referred to England Finder coordinates (E.F.co.).

Residues for scanning electron microscopy (SEM) were mounted on aluminium stubs and coated with gold-palladium. A Phillips XL 30 TMP from the MACN-Buenos Aires was used for detailed examination and imaging of selected specimens.

The terms used to describe morphological features are in accordance with the glossaries of Dettmann (1963), Kremp (1965), and Playford \& Dettmann (1996). We follow the taxonomic classification given by Traverse (1988) for the sporae dispersae genus Cladaitina and the discussions on turmal system therein.

Size measurements are presented in the format N1(N2-N3) $\mathrm{N} 4$, where $\mathrm{N} 1$ and $\mathrm{N} 4$ represent the minimum and the maximum values measured respectively, and N2-N3 the mean-range of most evaluated specimens. The number of measured specimens appears between brackets.

Abbreviations. IANIGLA, Paleopalynology Unit, of the Argentinian Institute of Nivology, Glaciology and Environmental Sciences; MACN, Museo Argentino de Ciencias Naturales "Bernardino Rivadavia", Buenos Aires, Argentina; MPLP, Mendoza-Paleopalinoteca-Laboratorio de Paleopalinología.

\section{SYSTEMATIC PALYNOLOGY}

Anteturma POLLENITES Potonié, 1931

Turma SACCITES Erdtman, 1947

Subturma MONOSACCITES Chitaley, emend. R. Potonié \& Kremp, 1954

Genus Cladaitina Maheshwari \& Meyen, 1975

Type species. Cladaitina dibnerae Maheshwari \& Meyen, 1975, p. 114, figs. 13 F-H, text-fig. 14.
Remarks and discussion. Maheshwari \& Meyen (1975) described microspores in situ from the sporangial membranes of Cladostrobus lutuginii Zalessky, 1918 and dispersed grains of uniform type from the same level, which were also in association with Rufloria Meyen, 1963 leaves from the Upper Permian, Central Siberia (=Asiatic Russia). They erected the genus Cladaitina to encompass such in situ and dispersae cordaitalean pollen grains characterized by the following main features: subcircular to oval, distally cavate, with saccus or pro-monosaccus proximally, completely encircling central body; saccus exine sculptured with closely placed small verrucae that form a negative reticulum; central body large without sculpture, usually almost filling prosaccus; haptotypic mark absent; dimensions ca. 35-55 $\mu \mathrm{m}$ in diameter.

Balme (1995, p. 221) commented that originally, the pollen of the Cladostrobus cone was illustrated and described as verrucate. According to Meyen (1987, p. 191) in the pollen grains of the Cladaitina type "the saccus bears inner polygonal projections with narrow slits in between, so that negative reticulum (intrareticuloid) appears", therefore, should not be considered saccate lacking of a true three-dimensional endoreticulum. The genus Reticulatina established originally by Koloda (1996) seemed to have similar morphology with the genera Cladaitina (Maheshwari \& Meyen, 1975) and Cordaitina (Zavialova et al., 2004) and they were considered previously rather similar and eventually conspecific but differing in details of their morphologies and ultrastructures (Zavialova \& Gomankov, 2009). The main feature differentiating the surface morphology of Reticulatina as observed under LM and SEM by Zavialova \& Gomankov (2009) is the reticulate sculpture by contrast to verrucate ornament in Cladaitina. Pollen grains of Cladaitinatype (without any indices of a regular reticulum) were repeatedly found in reproductive organs of Angaraland cordaites in contrast with circular reticulate pollen grains recorded as Reticulatina microreticulata (Efremova) Koloda, extracted from male cones of the primitive conifers (Kungurodendron sharovii Meyen) (Zavialova \& Gomankov, 2009, p. 84).

On the other hand, Jansonius et al. (1998, card 5051) pointed out that Meyen (1987) provided additional information on the structure of Cladaitina. Meyen (1987, p. 191) interpreted that in the pollen grains of Cladaitina type, the saccus embraces the body just from the equatorial and distal sides (not proximally as erroneously thought) and the degree of the saccus offlap the body varies considerably and in some grains, a saccus is unrecognizable. More recently, Taylor et al. (2009, p. 802-803) considered that sporae dispersae assigned to the genus Cladaitina are pollen grains oval in outline, monosaccate in which a weakly developed saccus covers the central body, except for a small region on the distal face; a monolete-dilete mark is present on the proximal face. In terms of Meyen's classification of saccus types (Meyen, 1987, p. 134, 248), pollen of Rufloriaceae is considered to be "quasimonosaccate" with proximal slit and, "monosaccate" grain if the pollen of Cladostrobus were considered intrareticuloid. All these terms imply a saccus (exoexine) embracing the intexine and becoming gradually thinner towards the proximal pole. Meyen (1987, p. 245, 
247-251) defined the terms "saccus", "quasisaccus" and "cavus" according to the stratification of the miospore wall. In gymnosperm microspores having the exine splitting between the nexine (intexine) and sexine (exoexine), the alveolar layer remains on the inner surface of the saccus (which acquires an intrareticulate structure) and the foot layer composes the surface of the body; in cavate forms the surface of the body is make up of the endexine. The cavities of our material lack any internal partitions and therefore cannot be treated for the moment as protosacci. The prosaccate/eusaccate condition should be evidently determined only by TEM as suggested by Zavialova \& Gomankov (2009).

In some grains of the La Veteada palynoflora a small scar is occasionally observed, other specimens do not show any definitely delineated aperture, possibly as a result of the orientation of the grains observed and/or it is hidden by the saccus; in some others the regions of reduced ectexine could be interpreted as areas of germination. Following Meyen (1997) and Gomankov (2000) we suppose that the aperture of these pollen grains (when present) is on the proximal side of the intexine (Zavialova \& Gomankov, 2009). The number of specimens studied in the La Veteada Formation allows us to consider that the presence of the scar mark is eventually observed or preserved just in some intexnal bodies and it could be related as a consequence of the preservational state and/or may be, due to the maturation stages of the grains.

The complete specimens of the La Veteada Formation broadly agree with the original diagnosis of Cladaitina.

\section{Cladaitina veteadensis sp. nov.}

(Figures 2-4)

Derivation of name. The name alludes to the La Veteada Formation from which the specimens were obtained.

Holotype. MPLP 8249(G) S48/4 (Figure 2.B).

Paratype 1. MPLP 8250(H) O50/0 (Figure 2.G); Paratype 2, MPLP 8248(H) K51/3 (Figure 2.F); Paratype 3, MPLP 8250(I) U41/3 (Figure 2.C), Paratype 4, MPLP 8249(F) U50/1 (Figure 2.H).

Type locality and stratigraphic horizon. Famatina Range, La Rioja Province, Argentina. La Veteada Formation, uppermost levels of the type section; Uppermost Permian.

Diagnosis. Monosaccate or quasi-monosaccate pollen grains, distally cavate. Amb subcircular to sub-oval, usually distorted by conspicuous folds. Exine two-layered in complete specimens: intexine laevigate or psilate, circular to subcircular in outline, giving an appearance of a darker "inner body"; exoexine partially adhered proximally to intexine and completely enveloping loosely the "intexinal body". Intexine sometimes shows eccentric disposition in obliquely flattened grains and filling variable space of detached exoexine. Exoexine, closely granulate, finely verrucate to rugulate. Proximally (on equatorial or oblique view), the sculpture is remarkably smaller where the exoexine is attached to intexine, being scabrate and giving the appearance of bared area.

Description. Monosaccate or quasi-monosaccate pollen grains, distally cavate. Amb subcircular to sub-oval, distorted by conspicuous folds of irregular disposition; irregular equatorial outline, mostly flattened. Exine two-layered in complete specimens: intexine laevigate (Figures 2D-F, I; $3 \mathrm{~K}-\mathrm{N}$; 4I-K) to psilate, thin, $0,5(0,8) 1,2 \mu \mathrm{m}$ thick, giving an appearance of a darker "inner body". Exoexine 0,5(0,7)1,3 $\mu \mathrm{m}$ thick, partially attached proximally to intexine and completely encircling the "intexinal body" forming entire limboid vesiculae but leaving distally a loosely broad "cavus". The inner cavity between the intexine and exoexine is difficult to observe in some specimens slightly or hardly flattened. Intexine circular, subcircular or suboval in outline, usually folded variably, rather stiff, sometimes shows eccentric disposition in obliquely flattened grains (Figure 2L) or almost centrally disposed (Figures 2A,G,J), and filling variable space of the detached exoexine (ratio intexine/exoexine, 0,70,8 for more than 60 percent of the total studied specimens for both axis) (Figure 2F); isolated intexinal bodies show a darker and thicker exine that probably indicates the area where the intexine adheres to exoexine (e.g. Figures 3G,M). Exoexine, closely ornamented equatorially and distally by grana (Figures 2B, C, 3E, 4G) and mainly by small verrucae (Figures $2 \mathrm{H}, 4 \mathrm{~A}-\mathrm{C}, \mathrm{L}, \mathrm{M}$ ) of variable sizes $0,8(1,6) 4,3 \mu \mathrm{m} \mathrm{x}$ $0,4(0,6-1) 2,6 \mu \mathrm{m}$ and shapes being circular, oval or polygonal, closely spaced, usually coalescent at their bases that may form rugulae of variable development and/or having appearance of an irregular and small negative reticulum. More robust verrucae and even clavate elements are projecting beyond the equatorial outline. Proximally, where the exoexine is adhered to intexine, the sculpture is remarkably smaller, scabrate, giving the appearance of a bared area (Figures 2A-B, 4D,H). In some isolated intexinal bodies, it is possible to observe a weak probable relictual small monolete (Figure 3J), dilete (Figure 3) or even trilete (Figure 3H) scar within a slightly darker and thicker-exine area. This intexinal thickening of the central body could be related to the attachment zone to the exoexine. It is difficult to see in entire specimens.

Within the assemblage, specimens that have been torn, splitted and/or broken do not posses an "intexinal bodies" which may have been detached and lost (Figures 3A-E), although the characteristic subcircular granulate to fine verrucate folded vesiculate exoexine permit to recognize them as belonging to this species. On the contrary, few intexinal bodies with broken exoexine remains still preserved can be observed (Figures 3F,O).

Dimensions. 210 measured specimens, in polar view. Overall equatorial diameter (exoexine) 48(71-100)160 x 42(6180) $120 \mu \mathrm{m}$; corpus (intexine) diameter 37(41-80)120 x $25(36-65) 90 \mu \mathrm{m}$; ratio intexine/exoexine, major axis $0,5(0,7-$ $0,8) 0,9$, minor axis $0,4(0,7-0,8) 0,9$; exoexine $0,5(0,6-0,8) 1,2$ $\mu \mathrm{m}$ thick; intexine, $0,5(0,6-0,9) 1,2 \mu \mathrm{m}$ thick. Specimens devoid of intexinal bodies (145 measured specimens); overall equatorial diameter (exoexine) 59(70-100)120 x 47(5684) $100 \mu \mathrm{m}$. Sculptural elements: verrucae $0,6(0,9-1,8) 4 \mathrm{x}$ $0,3(0,4-1) 1,7 \mu \mathrm{m}$ in basal diameter; grana $0,3(0,7-1,3) 2,6 \mathrm{x}$ $0,3(0,5-1,1) 2,6 \mu \mathrm{m}$ in basal diameter; rugulae $0,3(0,5-0,9) 1,8$ $\mu \mathrm{m}$ in width; sculpture of irregular spaced $0,1(0,3-0,6) 1,1 \mu \mathrm{m}$ apart; elements high $0,2(0,3-1) 1,5 \mu \mathrm{m}$ project from equator. 

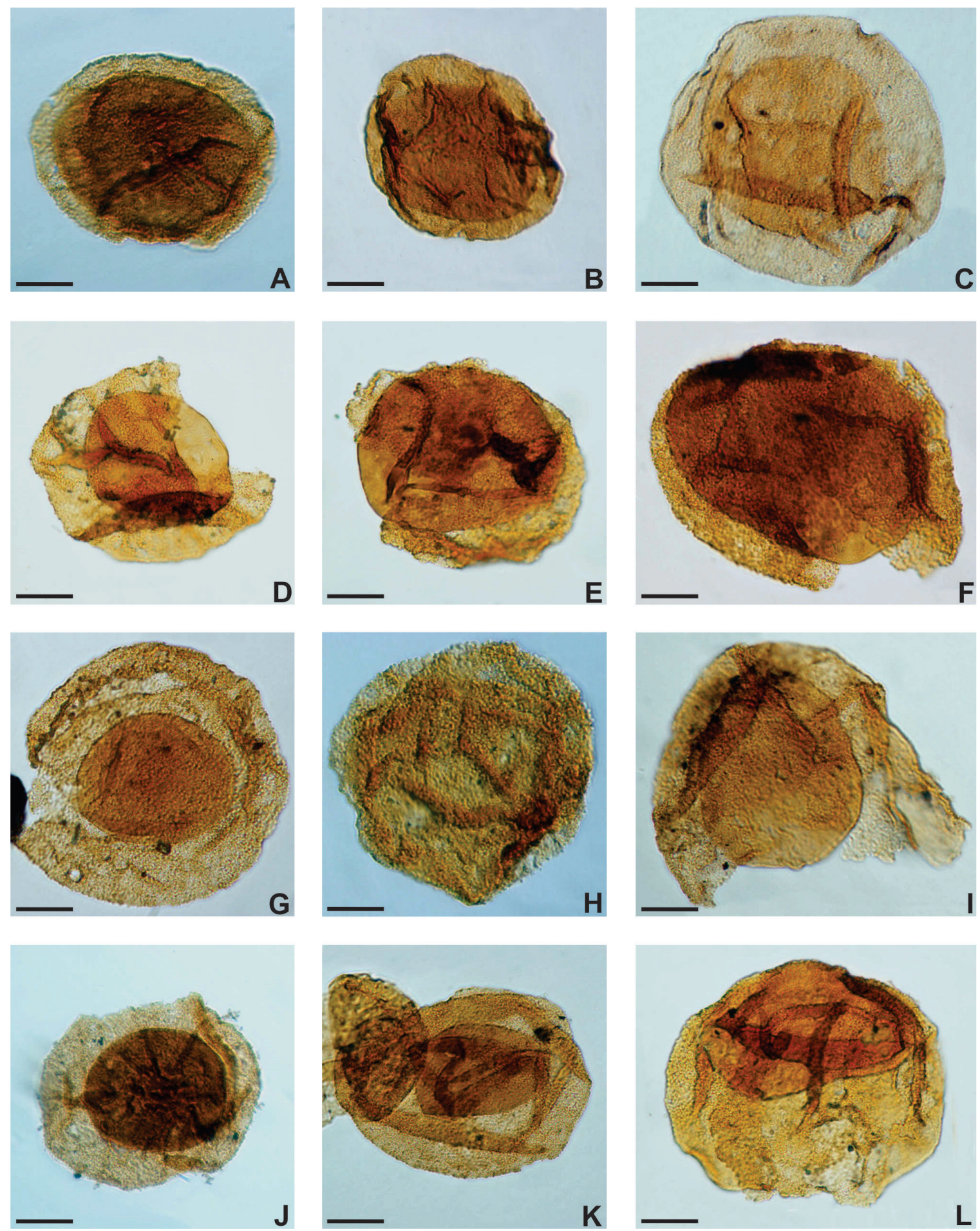

Figure 2. Cladaitina veteadensis sp. nov. A, MPLP $8250(\mathrm{H})$ R50/0, complete specimen showing intexine large, centrally disposed and filling most of the exoexinal cavity; B, MPLP 8249(G) S48/4, holotype, complete specimen, exoexine completely encircling central intexinal body, slightly folded, closely ornamented by grana; C, MPLP 8250(I) U41/3, paratype 3, complete large specimen, exoexine clearly finely granulate, grana closely distributed and projected on the exoexine outline (extrema lineamenta); D, MPLP 8250(H) P50/3, broken specimen showing intexinal central body psilate, exoexine granulate medium coarse; E, MPLP 8252(J) P48/3, broken specimen showing intexinal central body laevigate to psilate, large with respect to the exoexine; F, MPLP $8248(\mathrm{H}) \mathrm{K} 51 / 3$, paratype 2, complete specimen, intexine large, psilate to laevigate and exoexine coarsely ornamented by large grana transiting to small verrucae, closely distributed to appears a negative reticulum; ornamental elements projected to the equator; G, MPLP $8250(\mathrm{H})$ O50/0, paratype 1, complete specimen partially broken showing quite small psilate intexinal body, clearly detached from the large exoexine (cavate), closely granulate; H, MPLP 8249(F) U50/1, paratype 4, complete specimen, exoexine sculptured with closely placed small verrucae projecting to the equatorial outline; the coarse ornament hides the intexinal body; the arrow shows the intexine; I, MPLP 8253(I) M44/0, broken specimen showing psilate intexine central body which could has a relictual small mark; J, MPLP 8251(G) K33/0, small complete specimen with fine ornamentation; K, MPLP 8251(H) K52/0, specimen with small intexinal body in relation with the dimension of the exoexine, note deep folding of the exoexine; L, MPLP 8252(J) P48/3, specimen in equatorial view, clearly cavate distally; the arrow indicated the area where the intexine adheres to exoexine and the sculpture remarkably reduced. Scale bars $=20 \mu \mathrm{m}$. 
Isolated intexinal bodies (86 measured specimens): diameter 37(41-80)120 x 25(36-65)90 $\mu \mathrm{m}$.

In equatorial view (55 measured specimens): overall equatorial diameter (exoexine) 63(85-100)115 $\mu \mathrm{m}$; overall polar diameter (exoexine) 35(68-85)92 $\mu \mathrm{m}$; corpus (intexine) equatorial diameter 48(56-70)100 $\mu \mathrm{m}$; corpus (intexine) polar diameter 27(44-62)70 $\mu \mathrm{m}$.

Remarks and discussion. The genus Cladaitina was not considered as true monosaccate pollen by Maheshwari \& Meyen (1975), because the sexine (the sac) of these pollen grains lacks a true three-dimensional endoreticulum (Balme, 1995 , p. 221). On the contrary, as above was mentioned, Taylor et al. (2009, p. 803) consider that the pollen assigned to the sporae dispersae genus Cladaitina has a weakly developed saccus that covers the central body, except for a small region on the distal surface. In the La Veteada material we could not determine if the "cavity" has any internal sporopolleninous threads extended from the outer surface of the intexine (corpus) to the inner surface of the sexine (saccus) and therefore a true saccus with endoreticulations is not evident in this material. Then, we follow, for the moment Meyen's (1987) classification for the cordaitalean sporae dispersae pollen as previously has been discussed. TEM procedures are required to determine such saccate condition.

Folded inwards exoexines devoid of central body have been also observed among the fossils studied in this material resembling monosulcate/monocolpate type form genera. Thus, Maheshwari \& Meyen (1975) compared them of Ginkgocycadophytus-type, differing in lacking grana-verrucae type of ornamentation.

\section{Distinctions and comparisons with similar previously recorded form-genera}

The original size of the type species Cladaitina dibnerae was estimated ranging $c a$. $30-55 \mu \mathrm{m}$ from the illustration of Maheshwari \& Meyen (1975) (Balme, 1995, p. 221). Utting (1994, p. 63, pl. 9, figs. 15-17) erected C. kolodae Utting, 1994, the other species described up to now for the genus, from the Upper Permian of the Canadian Arctic embracing alete grains, amb circular to oval with the exoexine clearly reticulate on one surface and punctate on the other side, rather than closely spaced small verrucae as in the type species of the genus Cladaitina. C. kolodae is smaller $(42-68 \mu \mathrm{m})$ than the argentinian species. Utting (1994) compared and put under synonymy Reticulatina heterobrochata Molin et al., 1983 (nom. nud.) as wrongly referred by Utting, 1994, p. 63) with $C$. kolodae considering that species in nomen nudum because any diagnosis or description was given originally and the holotype not designated, as stated by Jansonius \& Hills (1990, card 4748). Koloda (1996) gave diagnosis of Reticulatina for pollen grains circular in polar view and ellipsoidal in equatorial view, being quasisaccate, with a saccus embracing the grain and becoming gradually thinner towards the proximal pole with a small proximal scar that occasionally was observed. Zavialova \& Gomankov (2009) pointed out that such circular reticulate pollen grains do not correspond to the generic diagnosis of Cladaitina, and therefore such pollen grains may be identified as $R$. microreticulata (Efremova) Koloda, 1996 rather than C. kolodae.

Closely ornamented granulate, torn and/or broken specimens of $C$. veteadensis sp. nov. devoid of inner body found in the La Veteada palynoflora closely resemble to that ruptured specimens illustrated by Balme (1979, p. 22, pl. 1, figs. 1-2) from the Upper Permian Kap Stosch, East Greenland. Balme (1979) suggested that inaperturate and scabrate thinwalled ruptured bodies referred as Inaperturpollenites nebulosus Balme, 1970 may have originated from nonvascular plants. He considered that despite of the generic name given to these forms does not suggest implication to spores or pollen grains of vascular plants. The size range of $C$. veteadensis sp. nov. can be more comparable to those dimensions given for I. nebulosus by Balme (1970: equatorial diameter, 71-83 $\mu \mathrm{m}$; 1979: equatorial diameter, 75-110 $\mu \mathrm{m})$ than that of the original equatorial size of the type species $C$. dibnerae being ca. $30 \mu \mathrm{m}$ (fig. 14, in Maheshwari \& Meyen, 1975, p.116). Tiwari \& Rana (1981, pl. 6, fig. 83) also just illustrated an alete pollen grain as I. nebulosus from the Lower Triassic of India, which may be similar to the Argentinian pollen grains herein described. Later on, Utting (1994, p. 64, pl. 9, fig. 18) referred I. nebulosus to an alete grain, with subcircular outline distorted by folding and granulate exine from the Upper Permian strata of Sverdrup Basin, Canadian Arctic that resemble also to Cladaitina veteadensis sp. nov. "empty" pollen grains. At first glance $C$. veteadensis nov. sp. and $I$. nebulosus Balme (1970) seem to have similar morphology and could be consider conspecific. Therefore, the last species I. nebulosus might have priority and it would require a new combination as C. nebulosa. However, we prefer to erect the new taxa once a revision of the original material described by Balme (1970) is required but impracticable now.

Other forms referred in the available literature as $I$. nebulosus have indeed more uncertain origin. Bharadwaj \& Tiwari (1977, p. 39, pl. 7, figs. 89-91) described and illustrated I. nebulosus from the Upper Permian of Raniganj Stage, India as microfossils incertae sedis being circular alete forms with thin, psilate to finely scabrate exine, having irregular to ring-like folding along the peripherical region. Similar characteristic features show those specimens illustrated by Hankel (1993) from the Early Triassic of Majunga Basin, Madagascar. Both last mentioned cases are more similar to the firstly described microfossils by Balme (1970, p. 413, pl. 21, figs. 25-27) assigned to I. nebulosus, whose remarkably finner sculptural pattern and the concentric folds close to the "vesicle" margin resemble certainly an algal origin. Looy et al. (2001, tab. 1, p. 7882) pointed out that in the Late Permian to Early Triassic of Greenland, the material that they observed has strong similarity between the form-genus Inaperturopollenites Pflug \& Thomson, 1953 broadly related to the conifer family Araucariaceae with the characteristic microverrucate exine structure and also with the sporae dispersae genus Cladaitina, pollen associated with the Rufloria-type Angaran cordaites.

Tiwari \& Moiz (1971) erected the genus Gondisphaeridium from the Upper Permian of Barakar Stage, Godavari Basin, India to encompass quite large alete miospores with granulose 
to verrucose ornamentation with spheroidal shape but usually flattened and variously folded along irregular directions. We consider that Indian material referred as G. levis Tiwari \& Moiz (1971, p. 102, Text-fig. 5) shows external similarity to irregularly folded miospores of $C$. veteadensis sp. nov. devoid of central intexine. The generic name Gondisphaeridium alludes to aquatic form genus but, the authors gave it a taxonomic status as miospores derived from vascular plants. The size of G. levis (equatorial diameter, 80-104 $\mu \mathrm{m}$ ) are also similar in size to $C$. veteadensis sp. nov.
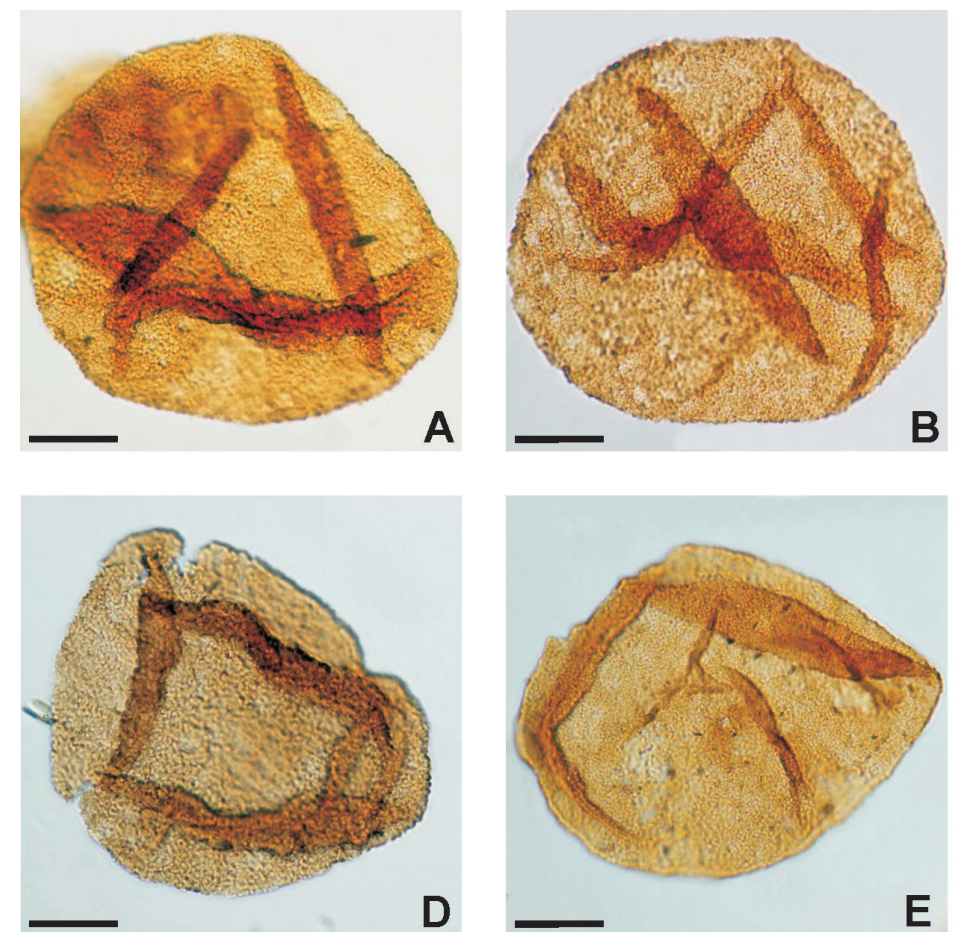

E

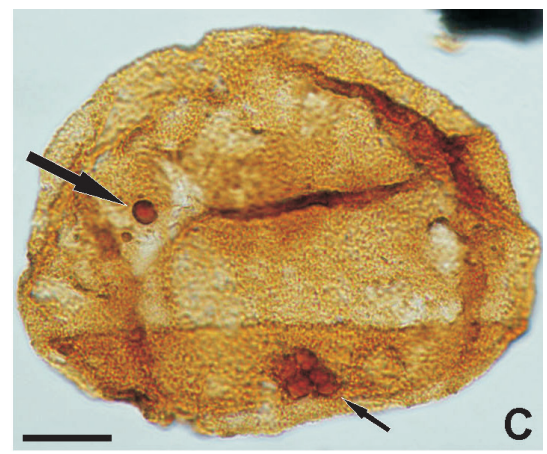

C

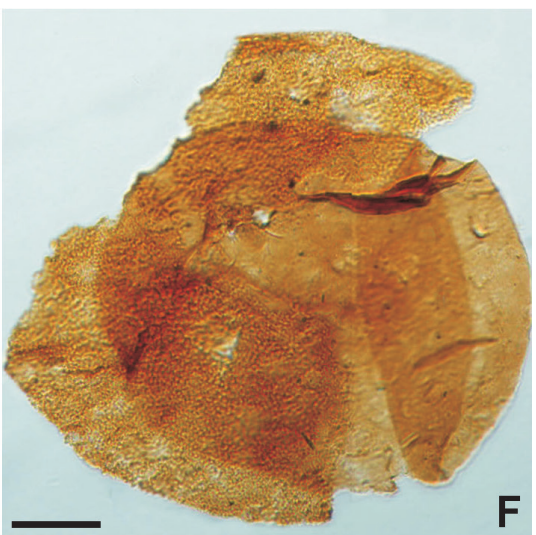

$\mathbf{F}$
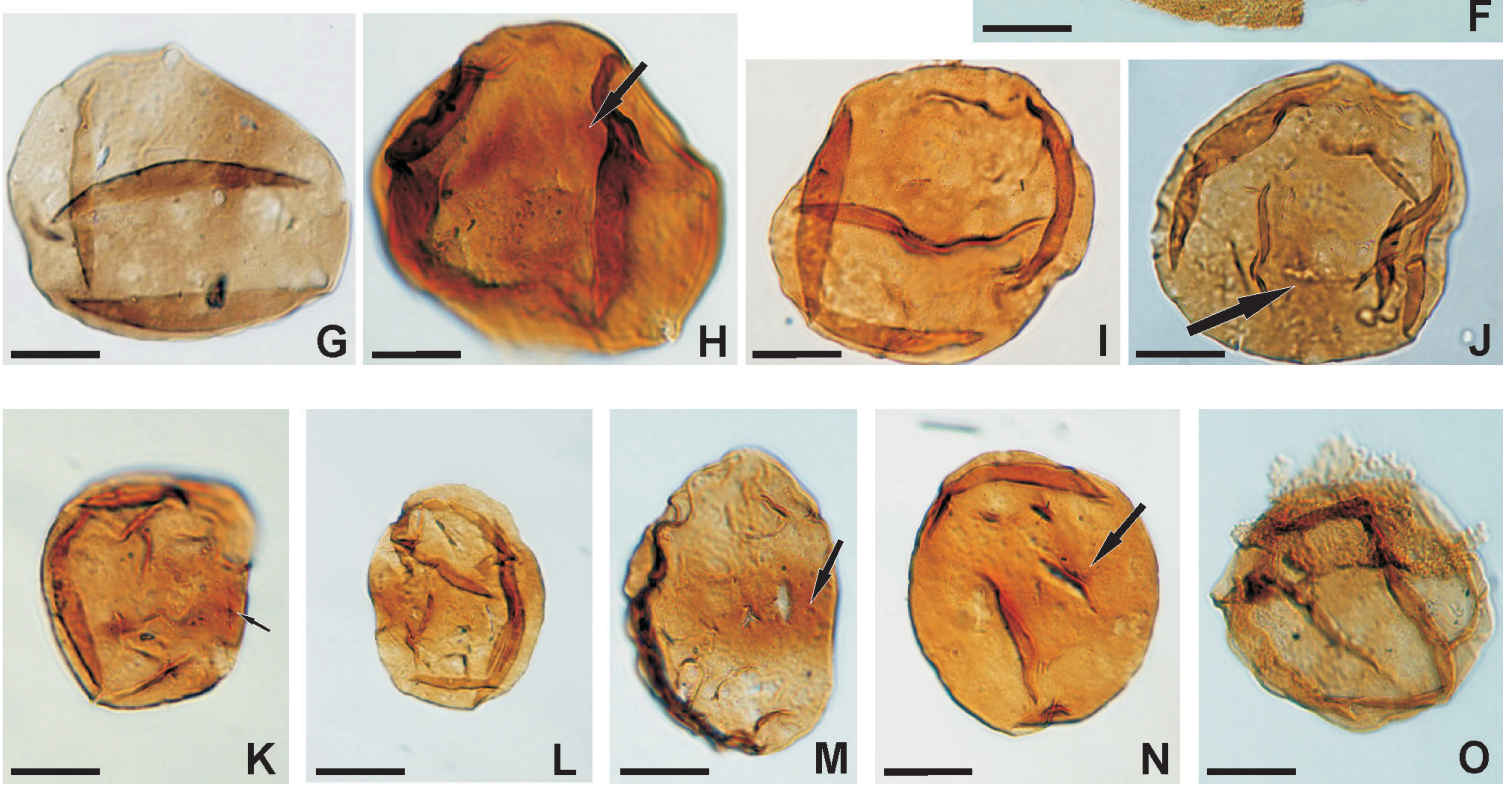

Figure 3. Cladaitina veteadensis sp. nov. A-E, specimens without inner body showing verrucate to granulate sculptures. A, MPLP 8249(F) R50/0, incomplete specimen of exoexine devoid intexinal central body, closely granulate that appears a negative reticulum, some granulae transit to small verrucae; B, MPLP $8250(\mathrm{H})$ P52/0, incomplete specimen of exoexine devoid intexinal central body, coarsely ornamented by small and closely spaced verrucae; C, MPLP 8248(H) N54/0, incomplete specimen of empty exoexine, showing Ubisch bodies/orbicules (arrows); D, MPLP 8250(G) Q52/0, incomplete specimen of empty exoexine irregularly folded; E, MPLP 8250(H) J49/5, incomplete specimen of empty exoexine, finelly granulate being almost an extreme of the ornament size; F, MPLP 8250(G) K50/0, broken specimen having large and folded intexinal central body and remains of the exoexine still adhered; G-O, isolated internal bodies (intexine) with psilate to laevigate exine, variably in shape, size and folding; G, MPLP 8250(G) M45/0; H, J-K, M-N, showing darker and thicker area (arrows) that probably corresponds to the proximal contact between exoexine and intexine and, showing the probable relictual scar; H, MPLP 8250(H) S52/0; J, MPLP 8250(H) G47/0; M, MPLP 8250(I) V45/0; I, MPLP 8248(G) V44/0; K, MPLP 8248(E) M33/0; L, MPLP 8249(F) F54/0; N, MPLP 8248(H) F42/0; O, MPLP 8249(F) $\cup 43 / 0$ - isolated intexinal central body having small remains of exoexine still adpressed. Scale bars $=20 \mu \mathrm{m}$. 

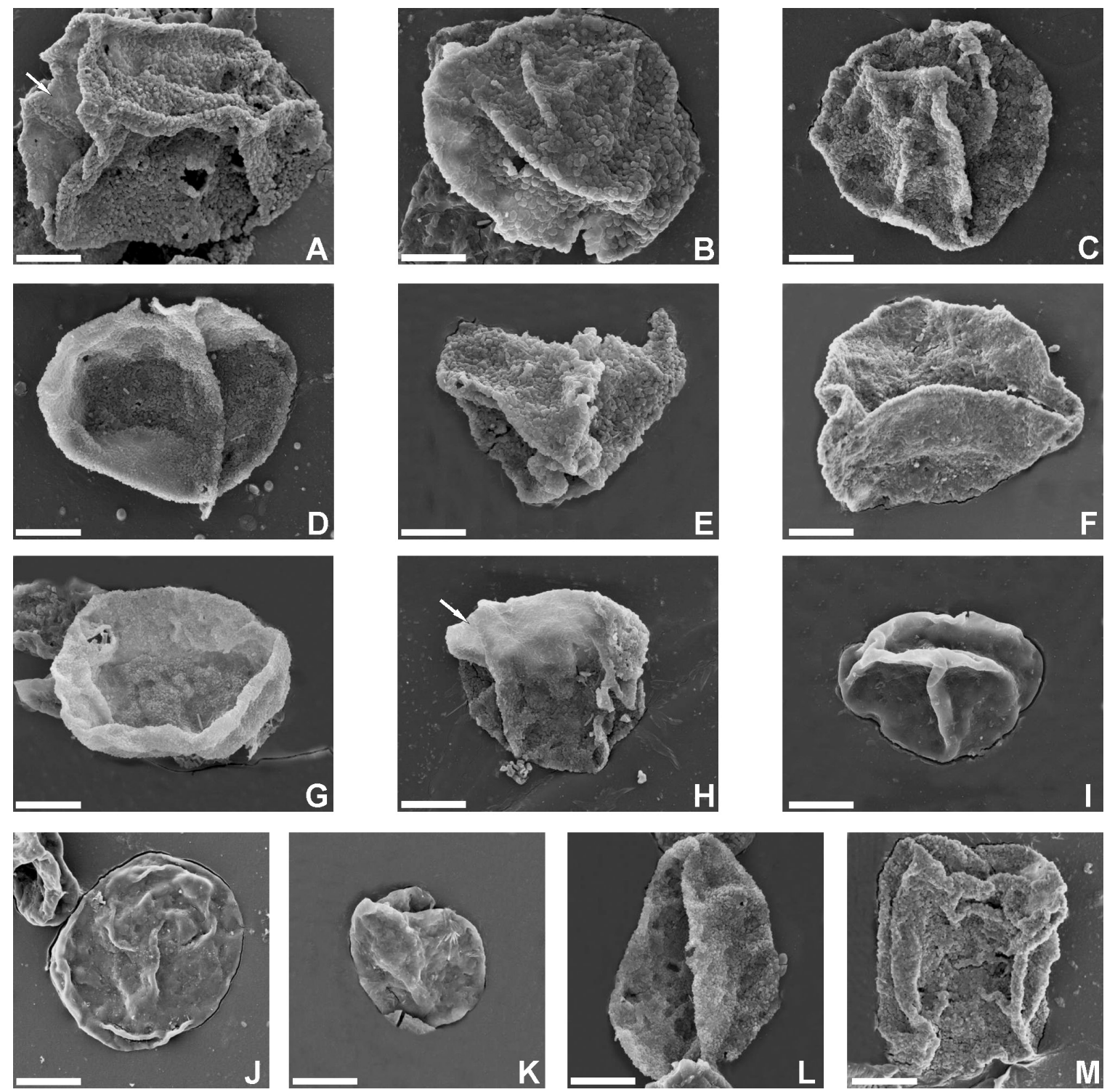

Figure 4. Cladaitina veteadensis sp. nov. A-C, E, L-M, specimens showing external ornamentation of the exoexine composed mainly by verrucate elements densely disposed: A, MEB 8249 359, broken and empty specimen, the arrow indicates reduced ornamentation on the proximal contact surface; B, MEB 8249 325, note on the left side, the smaller ornamentation on the contact area; C, MEB 8249 199, specimen with closely packed small verrucae; E, MEB 8249 299, torn and/or broken specimen; L, MEB 8249 233, granulate to verrucate specimen folded inward having boat shape; M, MEB 8249 345, specimen strongly flattened. D, F-G, specimens showing external finely granular ornamented exoexine: D, MEB 8249 240, exoexine closely granulate to finely regulate having appearance of an irregular and small negative reticulum; F, MEB 8249 174; G, MEB 8249 272; H, MEB 8249 296, specimen showing the position of the central body within exoexine and reduced ornamentation on the contact proximal surface (arrow). I-K, isolated internal bodies (intexine) showing laevigate exine and variably folded: I, MEB 8249 267; J, MEB 8249 156; K, MEB 8249 304. Scale bars $=20 \mu \mathrm{m}$.

Ottone \& García (1991, p. 229, pl. 5, fig. 3) assigned Araucariacites sp. to an inaperturate sub-circular pollen grain characterized by a closely packed grana and verrucate sculpture from the ?Uppermost Permian to ?Lowermost Triassic levels of the Puesto Viejo Formation, San Rafael depocenter, south of Mendoza Province, Argentina. The external appearance and the size of Araucariacites sp. (in Ottone \& García, 1991: equatorial diameter, $80 \mu \mathrm{m}$ ) suggest similarity with $C$. veteadensis sp. nov. herein described.

\section{Botanical affinities}

Studies of in situ grains from cone material of the Paleozoic Angaran pollen of Cladostrobus and associated sporae dispersae were referred originally to the genus Cladaitina and, therefore assigned to the Cordaitales, principally based on its association with Rufloria leaves (Maheshwari \& Meyen, 1975). Balme (1995) however, classified Cladaitina under asaccate gymnosperm pollen of Coniferopsida and also indicated that this genus embraces pollen of Rufloriaceae. Jansonius et al. (1998, card 5051) related the general organization of Cladostrobus to conifers of the families Labachiaceae and Voltziaceae. Recently, Taylor et al. (2009, p. 802-803) commented that the attachment of pollen sacs of such Cordaitales is similar to that of some cones included in the Voltziales. On the other hand, these last authors also mentioned that monosaccate pollen with proximal monolete-dilete mark occurs in Pechorostrobus from 
the Late Permian of the Pechora Basin in Russia, as we have also observed in our material. The phylogenetic position and origin of the Cordaitales remains under discussion (Taylor et al., 2009, p. 803-805).

Recently, studies on the morphology and exine ultrastructure of some dispersed Late Palaeozoic Angaran pollen of cordaitalean affinity, specially concerning to the pollen genera Cladaitina and Cordaitina was published by Zavialova et al. (2004). Gomankov (2009) demonstrated the evolutionary trend on changing morphologic and structural characters in Angaran cordaites and in early conifers pollen grains. He pointed out that the greater thickness of the endexine near the trilete mark on proximal face in Cordaitina indicates that this area functioned as an aperture suggesting that Angaran cordaites may be considered as prepollen as they have only one proximal aperture. Then, Gomankov (2009) concluded that the apparent further evolution of Cordaitina prepollen in Carboniferous and Permian families of Angaraland's cordaitales resulted, at the end of the Permian, in a curious bilaterally symmetrical prepollen with a depression on the proximal face and a single saccus enveloping the distal face. These morphological characters were represented by Cladaitina prepollen of Rufloriaceae.

\section{FINAL REMARKS}

A new cordaitalean pollen species of Cladaitina, namely Cladaitina veteadensis sp. nov. is described for the first time in the Permian strata of Argentina. The fact of the presence of Cladaitina pollen grains in the uppermost Permian strata of Argentina is of great significance, as these pollen grains are believed to be produced by representatives of Rufloriaceae, a family of Angaran cordaites. Although cordaites were constantly recorded in the Gondwana countries, the presence of the genus Cladaitina in Argentina can be considered as an evidence of the occurrence of Rufloriaceae in Gondwana.

Cladaitina veteadensis sp. nov. constitutes a characteristic common to abundant component of the palynological assemblage found in the type locality of the La Veteada Formation, Famatina Range, La Rioja Province, centralwestern Argentina. This contribution constitutes part of a complete palynological study of the type section of the La Veteada Formation which is current carryings on. On the preliminary palynological results overall, more than 90 genera of spores, pollen grains, algae and fungi have been recognized in the La Veteada assemblage collectively suggesting a latest Permian age.

First palynological evidences on the La Veteada miospores composition allow suggesting that it differs from others known Early-Middle Permian or Early-Middle Triassic microfloras of Argentina as summarizing follow: (i) broad dominance of species of the genera complex ProtohaploxypinusLunatisporites-Lueckisporites over other Stratiti taxa commonly recorded in well known southern South American Permian assemblages; (ii) scarce presence of the genera Vittatina, Weylandites, Marsupipollenites, Corisaccites, Staurosaccites between other taxa, conspicuously recorded in Early and Middle Permian south-american palynofloras; (iii) scarce quantity of other cordaitalean monosaccate pollen grains such as Potonieisporites, Cannanoropollis, Caheniasaccites, Plicatipollenites, Pakhapites, Barakarites which are abundant components in Late Carboniferous-Early Permian palynofloras recorded in southern South America; (iv) spores of lycopsid affinity are mainly represented by species of the genera Densoisporites-Densosporites-Secarisporites instead of the complex Lunbladispora, CristatisporitesKraeuselisporites-Vallatisporites broadly previously recorded in Permian palynofloras in Argentina; (v) common participation of non-striate bisaccate pollen grains assigned to the genera Alisporites-Falcisporites, Klausipollenites, Vitreisporites, Minutosaccus, Protodiploxypinus that are frequent in the Late Permian and abundant taxa in Triassic palynofloras of Argentina and (vi) scarce spores of Osmundaceae, Cyatheaceae, Gleicheniaceae, Sellaginellaceae, etc. which are abundantly recorded in Gondwana Triassic palynofloras.

Thus, the compositional features above briefly account suggest a Late Permian age for the La Veteada Formation palynoflora at Central Famatina, being youngest than Lueckisporites-Weylandites Biozone (LW: WordianoCapitaniano) (Césari \& Gutiérrez, 2001; Césari, 2007). Therefore, it is considered one of the youngest Permian palynofloral assemblage recorded up to now in Argentina and South America.

\section{ACKNOWLEDGEMENTS}

This research has been partially founded by the Agencia Nacional de Promoción Científica y Tecnológica, Argentina (Research Grants ANPCYT-PICT 32693 and 33630). Parts of the research that led to the revision of this material was finantially supported by the Consejo Nacional de Investigaciones Científicas y Técnicas (CONICET), Argentina (PIP No 0705 PRG and PIP No 11220090100605 AMZ). Special thanks are due to R. Astini and M. Ezpeleta who provided the palynological samples and the relevant geological and stratigraphic studies of the Famatina Range. Thanks to A. Moschetti (IANIGLA-CCT-CONICETMendoza) for palynological laboratory preparations of samples for light optical microscopy studies. F. Tricárico provided much-appreciated assistance and advice with scanning electron microscopy and photo-micrographic work. A. González and V. Zavattieri are thanked for their help in making and improving drawing figures. The manuscript reviewers, N. Jha (Birbal Sahni-India) and P.A. de Souza (UFRGS-Brasil) are greatly acknowledged for their extensive and very helpful comments and suggestions to improve and clarify the original version of this paper.

\section{REFERENCES}

Balme, B.E. 1970. Palynology of Permian and Triassic Strata in the Salt Range and Surghar Range, West Pakistan. University of Kansas, Department of Geology, Special Publication, 4:304-453. 
Balme, B.E. 1979. Palynology of Permian-Triassic boundary beds at Kap Stosch, East Greenland. Meddelelser om Grønland, udgivne af Kommissionen for Videnskabelige Undersøgelser $i$ Grønland, 200:1-37.

Balme, B.E. 1995. Fossil in situ spores and pollen grains: an annotated catalogue. Review of Palaeobotany and Palynology, 87:81-323. doi.org/10.1016/0034-6667(95)93235-X

Bharadwaj, D.C. \& Tiwari, R.S. 1977. Permian-Triassic miofloras from the Raniganj Coalfield, India. The Palaeobotanist, 24:2649.

Césari, S.N. 2007. Palynological biozones and radiometric data at the Carboniferous-Permian boundary in western Gondwana. Gondwana Research, 11:529-536. doi.org/10.1016/j. gr.2006.07.002

Césari, S.N. \& Gutiérrez, P.R. 2001. Palynostratigraphy of Upper Paleozoic sequences in central-western Argentinian. Palynology, 24:113-146. doi:10.2113/0240113

Dávila, F.M.; Astini, R.A. \& Ezpeleta, M. 2005. Sucesiones lacustres postgondwánicas-preandinas en la región de Famatina (La Rioja y Catamarca). Revista de la Asociación Geológica Argentina, 60:88-95.

Dettmann, M.E. 1963. Upper Mesozoic microfloras from southeastern Australia. Proceedings Royal Society Victoria, 77:1-148.

Ezpeleta, M. 2009. El Paleozoico Superior de la región central del Famatina: un enfoque tectosedimentario. Universidad Nacional de Córdoba, Tesis Doctoral, $336 \mathrm{p}$.

Gomankov, A.V. 2000. On pollen evolution in gymnosperms in general and pinopsids in particular. Paleontological Journal, 34:S14-S19.

Gomankov, A.V. 2009. Pollen evolution in Cordaites and early Conifers. Palaeontological Journal, 43:1245-1252. doi.10.1134/ S0031030109100062

Gutiérrez, P.R.; Zavattieri, A.M.; Ezpeleta. M. \& Astini, R.A. 2011. Palynology of the La Veteada Formation (Permian) at the Sierra de Narváez, Catamarca Province, Argentina. Ameghiniana, 48:154-176.

Hankel, O. 1993. Early Triassic plant microfossils from Sakamena sediments of Majunga Basin, Madagascar. Review of Palaeobotany and Palynology, 77:213-233. doi.org/10.1016/00346667(93)90005-F

Jansonius, J. \& Hills, L.V. 1990. Genera File of Fossil Spores. Supplement. Special Publication. Department of Geology, University of Calgary, Canada. Cards 4585-4811.

Jansonius, J.; Hills, L.V. \& Hartkopf-Fröder, C. 1998. Genera file of fossil spores. Supplement 12. Special Publication, Department of Geology and Geophysics, University of Calgary, AB, Canada T2N 1 N4.

Koloda, N.A. 1996. New data on the systematics of the Permian quasimonosaccate pollen. Trudy Instituta Geologii, Komi Nauchnovo Tsentra UrORAN. Transactions of the Institute of Geology, Komi Science Centre, Uralian Department Russian Academy of Science, 89:49-59.
Kremp, G.O.W. 1965. Morphologic encyclopedia of palynology. Tucson, University of Arizona Press, 263 p.

Looy, C.V.; Twitchett, R.J.; Dilcher, D.L.; Van Konijnenburg-Van Cittert J.H.A. \& Visscher, H. 2001. Life in the end-Permian dead zone. Proceedings of the National Academy of Sciences, 98:7879-7883. doi/10.1073/pnas.131218098

Maheshwari, H.K. \& Meyen, S.V. 1975. Cladostrobus and the systematics of cordaitalean leaves. Lethaia, 8:103-123. doi:10.1111/j.15023931.1975.tb01306.x

Meyen, S.V. 1987. Fundamentals of Palaeobotany. London, Chapman and Hall, 432 p.

Meyen, S.V. 1997. Permian conifers of Western Angaraland. Review of Palaeobotany and Palynology, 96:351-447. doi.org/10.1016/ S0034-6667(96)00046-2

Molin, A.V.; Kalashnikov, N.V.; Koloda, N.A. \& Melnikova, S.O. 1983. New data on palaeontologic characteristic of the Late Permian of the Kanin Peninsula. Transactions of the Institute of Geology, Komi Filio, Academy of Science, USSR, Phanerozoic Palaeontology of the North of the european part of the USSR., 43:7-25.

Ottone, E.G. \& García, G.B. 1991. A Lower Triassic miospore assemblage from Puesto Viejo Formation, Argentina. Review of Palaeobotany and Palynology, 68:217-232. doi. org/10.1016/0034-6667(91)90025-X

Playford, G. \& Dettmann, M.E. 1996. Spores. In: J. Jansonius \& D.C. McGregor (eds.) Palynology: principles and applications, American Association of Stratigraphic Palynologists Foundation, 1:227-260.

Taylor, T.N.; Taylor, E.L. \& Krings, M. 2009. Paleobotany: the biology and evolution of fossil plants. $2^{\mathrm{a}}$ ed. Burlington, Academic Press, 1230 p.

Tiwari, R.S. \& Moiz, A.A. 1971. Palynological study of Lower Gondwana (Permian) coals from Godavari Basin, India. I. On some new miospore genera. The Palaeobotanist, 19:95-104.

Tiwari, R.S. \& Rana, V. 1981. Sporae disperae of some Lower and Middle Triassic sediments from Damodar Basin, India. The Palaeobotanist, 27:190-220.

Traverse, A. 1988. Paleopalynology. Boston, Unwin Hyman, 600 p.

Turner, J.C.M. 1964. Descripción geológica de la Hoja 15c, Vinchina (provincias de Catamarca y La Rioja). Boletín de la Dirección Nacional de Geología y Minería, 100:1-81.

Utting, J. 1994. Palynostratigraphy of Permian and Lower Triassic rocks, Sverdrup Basin, Canadian Arctic Archipelago. Bulletin of the Geological Survey of Canada, 478:1-87.

Zavialova, N.E. \& Gomankov, A.V. 2009. Occurrence of angiospermlike ultrastructural features in gymnosperm pollen from the Permian of Russia. Review of Palaeobotany and Palynology, 156:79-89. doi.org/10.1016/j.revpalbo.2009.02.002

Zavialova, N.E.; Gomankov, A.V.; Yaroshenko, O.P. \& Rovnina, L.V. 2004. Morphology and ultrastructure of some monosaccate pollen grains of Cordaitina Samoilovich, 1953 from Permian of Russia. Acta Palaeobotanica Polonica, 44:3-35.

Received in August, 2011; accepted in April, 2012. 